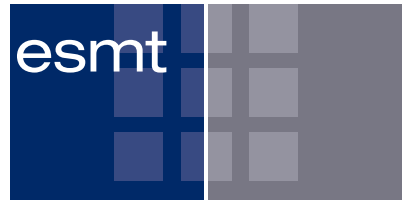

December 1, 2009

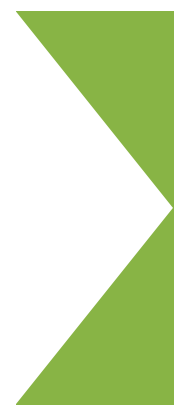

\title{
ESMT
}

WORKING PAPER

ESMT No. 09-008

A Framework for Monitoring Relational Quality in B2B Technology Partnerships

Francis Bidault, ESMT

Manfred Lüth, University of Nice

Olaf Plötner, ESMT

ISSN 1866-3494 


\title{
Abstract
}

\section{A Framework for Monitoring Relational Quality in B2B Technology Partnerships}

\author{
Author(s): Francis Bidault, ESMT \\ Manfred Lüth, University of Nice \\ Olaf Plötner, ESMT
}

The purpose of this paper is to propose a framework for the monitoring of new technology introduction in a B2B environment. We focus on B2B environments, i.e. on projects where a new technological solution is implemented (and often jointly developed) with a client being either a company or an organization.

In such a situation, where a supplier and its client agree to implement a new technology, both are exposed to a risk. The management of these risks can be handled through a couple of approaches: control or trust. The management literature has put a lot of attention on these two modes that play an important role because they drive the quality of the relationship between partners. We will explore their respective roles and build a methodology to monitor them along the life of a buyer-supplier relationship aiming at implementing new technology.

Keywords: technology partnerships, trust, relational quality

J EL Classification: M19 


\section{Introduction}

The purpose of this paper is to propose a framework for the monitoring of new technology introduction in a B2B environment. The need for this approach arises from the very poor rate of success of technological innovation that has been estimated at a low 1 in 7 for new production developments (Kahn, 2005). Failure rates ranging between 85 97\% were reported in other studies (Maital, 1994; Gerybadze, 2004; Berth, 1993) stressing the relevance of the search for solutions addressing this issue.

Academic scholars and consultants have devoted substantial efforts to reduce the mortality rate in new product introductions. In spite of an abundant literature, this rate did not decline much over the past few decades. It still takes about 7 or 8 new product ideas for a successful market introduction, even though progress in the screening of innovation ideas avoids costly withdrawals later on in the development funnel.

On the other hand, the drivers of success for new technology introduction certainly differ depending on the specific market conditions. Here we focus on B2B environments, i.e. on projects where a new technological solution is implemented (and often jointly developed) with a client being either a company or an organization, as opposed to a "consumer".

Technological innovation has become a "catch word" that covers a great variety of realities. At the most general level, technological innovation can be defined as "the process through which new (or improved) technologies are developed and brought into widespread use" (Ambuj Sagar, 2006). We will need however, and this is the purpose of section 1 below, to refine this definition further to fit our goal better.

In any case, when two companies, a supplier and its client, agree to implement a new technology, both are exposed to a risk, actually a set of risks. The management of these risks can be handled through a couple of approaches. The management literature has put a lot of attention on two modes that seem to be playing an important role because they drive the quality of the relationship between partners: control and trust. We will explore their respective roles and build a methodology to monitor them along the life of a buyersupplier relationship aiming at implementing new technology.

We will first explore the impact of technological innovation and show that, consistent with a string of theories originating with Joseph Schumpeter (1934), its study is best 
undertaken at the network level since, except for minor innovations (e.g. face lifts), technology changes generally affect several stages in the firm's value chain.

We will then look at the findings in the extensive literature concerning the key success factors for new product development. We will observe that some of these factors clearly advocate a management approach based on control, while others are rather insisting on trust between partners involved.

The meaning and the mechanisms of control will then be defined in the context of $B 2 B$ relationships. The theory of control in the management literature is quite broad, sometimes even including informal forms of control through socialization and trust. We contend that such a broad understanding is not adequate when it comes to the type of relationships we research. Rather, we will focus on the administrative forms of control based on hierarchical or bureaucratic processes.

We will contrast the "control" approach with that based on trust. Trust is a complex concept that encompasses several dimensions. It has been extensively researched in the past two decades and rich findings have been produced. We will draw on this to discuss how trust can relate to the implementation of technological innovation as a supplement to control.

Our key concepts being defined, we will be able to articulate our model for a monitoring of technological innovation in a B2B context. And we will finally explain how we intend to test it in the next steps of this research program. 


\section{Technological innovation and the value chain}

Since Joseph Schumpeter's pioneering work on the role of innovation on economic growth, a substantial amount has been discovered regarding the dynamics of technological innovation.

Schumpeter viewed economic development as a series of expansion and contraction phases. Crises following a contraction phase create opportunities for entrepreneurs to introduce new business ideas that in turn trigger a new expansion phase that eventually slows down and get the economy to a plateau and even a decline, for lack of further innovations, until new entrepreneurs introduce new business ideas. Schumpeter's concept of innovation is not limited to new products, but includes several other categories that shed light on its very nature: new production processes, new usage of existing material, introduction of existing technology to new markets and finally new ways of organizing. While some innovations belong to only one category, some are new solutions in several. For instance, the carving ski is merely a new shape of skis and for this reason it is perfectly compatible with pre-existing production processes, material, distribution channels and markets. By contrast, the commercial introduction of low-cost electronic watches was incompatible with pretty much all activities of the micromechanical watch industry.

Innovations like the electronic watch can be called "systemic" to the extent that they are not limited to one activity in the value chain and therefore have the most far-ranging economic impacts. These kinds of innovations, as pointed out by Schumpeter, do not come continuously and evenly across industries. Instead, they tend to come in leaps that affect often several industries together. Such was the case of the steam engine which in the $19^{\text {th }}$ century made a whole set of new businesses possible. The advent of microelectronic in the second part of the $20^{\text {th }}$ century also triggered the development of a whole series of industries from the microcomputer to mobile telephony, digital photography and, indeed, electronic watches. These are times of "creative destruction". These are times when past capabilities can be made useless because new technology can provide the consumer value at a lower cost and / or at a better quality.

Following up on Schumpeter's macro-economic model, James Utterback (1994) proposed a model of the industry life cycle that presents technological innovations as a sequence. Initially, product innovation is the area where entrepreneurs are the most active in a new industry. A flurry of new product designs is presented as entrepreneurs grope to find the “ultimate design" which clients will prefer (Steve Hamm, 2009). This highly competitive 
phase eventually reveals winning and losing designs, and gradually firms will converge to a dominant design, the one that is selling the best in the market. At this point, the focus of competition will start shifting towards efficiency. Now that the optimum product design has been identified, firms will look for ways to produce it as efficiently as possible, i.e. at the lowest cost and with steady quality. Technology development attention then turns away from product design and starts focusing on production processes. Typically, this phase will continue as the industry grows and then matures. Only when eventually the industry starts its decline, as new substitutes emerge, will all innovation efforts on the "old" technology recede.

Substitute solutions to existing needs often rely on new combinations of technologies that give rise to a new set of firms. The shift from silver haloid photography to digital solutions is a vivid illustration of this model. In Utterback's model, as in Schumpeter's, technological innovation does not "happen" within the firm but is the results of interaction between the firms, its clients, and its suppliers.

Christensen (1997) pursued this line of research on the dynamics of innovation with the analysis of the competition between incumbents (insiders to an industry) and new entrants. He observed that the leaders in an industry often do not survive major technological change (disruptive technologies) and that this change is on the contrary favorable to new entrants. This is because these innovations typically require new capabilities that incumbents do not possess and do not seem keen to acquire, preferring instead to stick to their "business". The incumbents have a strong preference for "sustaining" innovations, those that do not require new capabilities but rather bring more business to the existing value chain and capabilities. Besides, they often underestimate the threat of disruptive innovations due to their dependence on the existing value chain and their partners.

The overall pattern that we observe in these theories is the fact that innovation as a process must be studied at level of the value chain, not at the level of the firm or even at the market level. Innovations are borne, and sometimes killed, at this level, when the lead players in the value chain promote or oppose it. The firm, in isolation, cannot succeed unless it finds allies, supporters, partners in the value chain to support the innovation. This process is especially strong in B2B markets where clients are generally fewer in numbers, compared to consumer markets, and typically enjoy stronger technological capabilities as well as bargaining power. That is particularly the case of the most "radical" innovations ("new-to-the world" or "new-to-the-firm") since they 
typically represent a higher risk which clients need to mitigate through close monitoring of the implementation.

This paper aims to propose a framework that could help both partners manage more safely the implementation process. It suggests playing on the two opposing sites of management equation: control and trust.

\section{Exploring the Key Success Factors of Innovation}

There has been quite some work done on the identification of factors associated with the success of new products. Early on, there was the pioneering work of Rothwell, (1972) and the Science and Policy Research Unit in the UK that was followed by the numerous research projects of Cooper \& Kleinschmidt and others (e.g. Cooper \& Kleinschmidt 1987; Montoya-Weiss \& Calantone, 1994). Recently several articles have proposed a synthesis of the many articles addressing this question (Henard \& Szymanski, 2001; Ernst, 2002; Barczak et al., 2009) providing the basis for a comprehensive view of the field on which we can draw interesting learning points.

Even though we acknowledge that new product development is a specific type of innovation, the findings reveal a few important drivers of innovation success. In this section, we will review these findings and show that they point to the need for both control and trust for the implementation of technological innovation.

\section{What makes product development successful?}

To begin with, it is useful to note that very many factors seem to play a role in the success of new product development. Reviewing over 60 different studies addressing this research question, Henard and Szymanski (2001) have collected the predictors reported to have a correlation in a sufficient number of studies (at least 10). They found 24 predictors that they then grouped in four categories (See Figure 1 below). 
Figure 1: Main success factors of new product development

\begin{tabular}{|c|c|c|c|}
\hline $\begin{array}{c}\text { Product } \\
\text { Characteristics }\end{array}$ & Market Context & $\begin{array}{c}\text { Process } \\
\text { Characteristics }\end{array}$ & $\begin{array}{c}\text { Strategic } \\
\text { \& organizational } \\
\text { Context }\end{array}$ \\
\hline $\begin{array}{l}\text { Product advantage } \\
\text { Product meets custo needs } \\
\text { Product price } \\
\text { Product techno sophisticat } \\
\text { Product innowativeness }\end{array}$ & $\begin{array}{l}\text { Likelihood of competitive } \\
\text { Response (-) } \\
\text { Competitive response } \\
\text { intensity (-) } \\
\text { Market potential }\end{array}$ & $\begin{array}{l}\text { Structured approach } \\
\text { Predent task proficiency } \\
\text { Marketing task proficiency } \\
\text { Technological proficiency } \\
\text { Launch proficiency } \\
\text { Reduced cycle time } \\
\text { Market orientation } \\
\text { Customer input } \\
\text { Cross-functional integration } \\
\text { Cross-funclional commun } \\
\text { Senior mgmt support }\end{array}$ & $\begin{array}{l}\text { Marketing synergy } \\
\text { Technological synergy } \\
\text { Order of entry } \\
\text { Dedicated HR } \\
\text { Dedicated R\&D resources }\end{array}$ \\
\hline
\end{tabular}

Ten of them seem to show a relatively high level of correlation (bi-variate correlation coefficients) across several studies: market potential (0.54), dedicated human resources $(0.52)$, marketing task proficiency $(0.50)$, product meet customer needs $(0.50)$, product advantage $(0.48)$, pre-development task proficiency $(0.46)$, dedicated R\&D resources $(0.45)$, technology proficiency $(0.43)$, launch proficiency $(0.43)$, order of entry $(0.42)$.

The diversity of these predictors is obviously striking, and so are the managerial implications that can be derived from. While some point to the need to reduce risk, others suggest rather assuming the risk.

Many factors would imply a systematic planning and execution of the new product development process. This is obviously the case of the third group of factors such as having "a structured approach", or "proficiency in pre-development", "marketing” or "technology development" tasks. The need for marketing or technological synergy between the new product and the company's other products also points to this direction. In other words, rigor in execution and consistency of development activities with the goal as well as across the various tasks are called for to reduce the risks associated with new product development. Good project planning and execution is shown by these studies to be necessary for the success. Consequently, the innovator must reduce its risk exposure on all factors that are under its control. 
Other factors, on the contrary, imply risk taking. Some decisions in product development are certainly risky because the environment (market and competition) might change unexpectedly. "Product advantage", for instance, means that new products that enjoy an advantage over their competitors are more likely to succeed in the market. But a new product's advantage definitely depends on what competitors will be offering as well as what customers will expect at the time when the product is launched, both of these are continuously evolving. At some point, nevertheless, the innovator must decide to "freeze" its design and proceed with the final development and launch. The same goes for "Product innovativeness" and obviously "intensity of competitive response", "price" and any other factors where other players' actions result in the innovator being exposed to a risk. This is the famous syndrome of the "moving target" hindering the success of many new products.

While risk reduction is managed through planning and systematic execution, risk taking requires a very different approach based on flexibility and adaptation as the market and competitive environment shift.

\section{Control vs. Trust in Joint-Innovation Management}

If we now consider these predictors in the context of open innovation, and more specifically projects where two innovators are developing a new product together, new challenges arise. While risk reduction through planning should be relatively difficult but feasible, risk taking seems more difficult to assume.

Risk reduction in product development, as we explained earlier, implies to plan every step that is under the control of the innovator. When there are two actors in the innovation process, planning is as necessary. Control however is more complex. It is not just controlling the joint-process. It is also about the control of the other partner in the innovation. Risk reduction calls for controlling what the other party does. To a large extent this is achieved through contracting, but not exclusively. There are other forms of control such as the display of threats to discontinue the partnership, for instance.

On the other hand, risk taking is also on the agenda. We saw that risk taking requires an ability to constantly monitor new developments in the environment and to adjust to new demands and new opportunities. With two (or more) partners, flexibility is far more difficult to achieve. Flexibility implies the ability to change important project priorities, such as objectives, timing, the amount of resources needed, etc. But a change in the environment of the projects generally opens several new options. These are as many 
opportunities to disagree for the partners. But flexibility can only be achieved if the partners can agree on the new priorities without too much delays, disputes or renegotiation (Bidault \& Cummings, 1993).

Unfortunately, too often, partnerships and alliances fall victims of change due to their poor ability to adapt (Bleeke and Ernst, 1993). The capacity of adaptation is quite demanding, it requires the ability to find an agreement on the new project priorities without much delay. A single company can make a decision faster than a partnership thanks to the hierarchical structure that gives it relatively high control on the use of resources. But control in a joint venture is not as straightforward as within a firm, simply because there are two parties involved in the decision. Therefore, another adaptation process is needed. This is the role that trust between partners can play.

We adopt here the widely accepted definition of Rousseau, Sitkin, Burt \& Camerer (1998) according to whom trust is “... a psychological state comprising the intention to accept vulnerability based upon positive expectations of the intentions of behavior of another". Trust has been found to improve the management of relationships. An article by Zaheer, McEvily and Perrone (1998) for instance suggests that “...trust reduces the inclination to guard against opportunistic behavior". Dyer and Chu (2003) conducted a comparative study of buyers and suppliers in Japan, Korea and the U.S. and showed that trust between business partners results in lower transaction costs, especially those that incurred prior to the outsourcing project.

Control can be defined at the simplest level as the influence that a person or organization has over the actions of another person or organization. This simple definition has been complemented with many others that address the nature, the process as well as the level of influence (Ouchi, 1979). In this article, Ouchi proposes a very extensive concept of control that, he suggests, can be exercised through market mechanisms, hierarchies and clans. Control in organizations (hierarchies) is implemented through personal surveillance and the establishment of rules (budget, limits, rules, standards, etc.). The other mechanisms (market and clans) provide a very different sort of control that originates from the effect of external pressure: competition in the case of markets and the socialization process in the case of clans. These other mechanisms are less interesting for the study of technology-oriented partnership because they do not provide an adequate treatment of two important contextual dimensions of the relationship: the economic context and inter-personal trust. 
Das \& Teng (1998) have explored in great depth the balance between control and trust and shown that these drivers are always both present in strategic alliances. They jointly influence what Das \& Teng call the "confidence" in the partner's cooperation, i.e. "the perceived level of certainty that its partner firm will pursue mutually compatible interests in the alliance rather than act opportunistically". The levels of control and trust, in turn, are driven by the implementation of control mechanisms as well as trust building processes. An interesting finding of these authors is the fact that while both mechanisms are necessary, the levels of control and trust are not substitutes or even complements, but are rather supplemental, meaning that both can grow simultaneously and result in higher levels of confidence. Das \& Teng insist on the importance of having a high confidence to start an alliance. However, we know that the main challenge to alliances is their lack of stability and their inability to cope with adaptation. Consequently, we think that there is a need to understand better how on-going partnerships can weather significant changes in their environment.

In a joint-innovation project, control can be exercised at two levels as pointed out by Das \& Teng (1998): control over the joint-project, and control over the partner. The first one is obviously necessary: this is simply a matter of good management practice. The second one is also necessary because the project eventually depends on the contribution by both partners, so there is a need to also monitor what the other partner contributes.

Arino, de la Torre and Ring $(2004,2005)$ proposed an interesting concept in this respect: relational quality. This concept is proposed as an alternative to inter-organizational trust. It is "the extent to which the principals and the agents of alliances partners feel confident with their counterparts' organizations" (Arino et al. 2005, p.15). Relational quality influences the openness of individuals to sharing information due to the absence of fear regarding potential abuse. As such "when positive, relational quality facilitates inter-organizational collaboration, expedites inter-organizational action, and encourages the exploration of new opportunities leading to value creation for both organizations" (Arino et al. 2005, p.16). This concept is particularly appropriate to view partnerships and alliances over time since relational capital is both a driver of future cooperative attitude in the partnership, as well as the result of past cooperation (see Figure 2 below). 


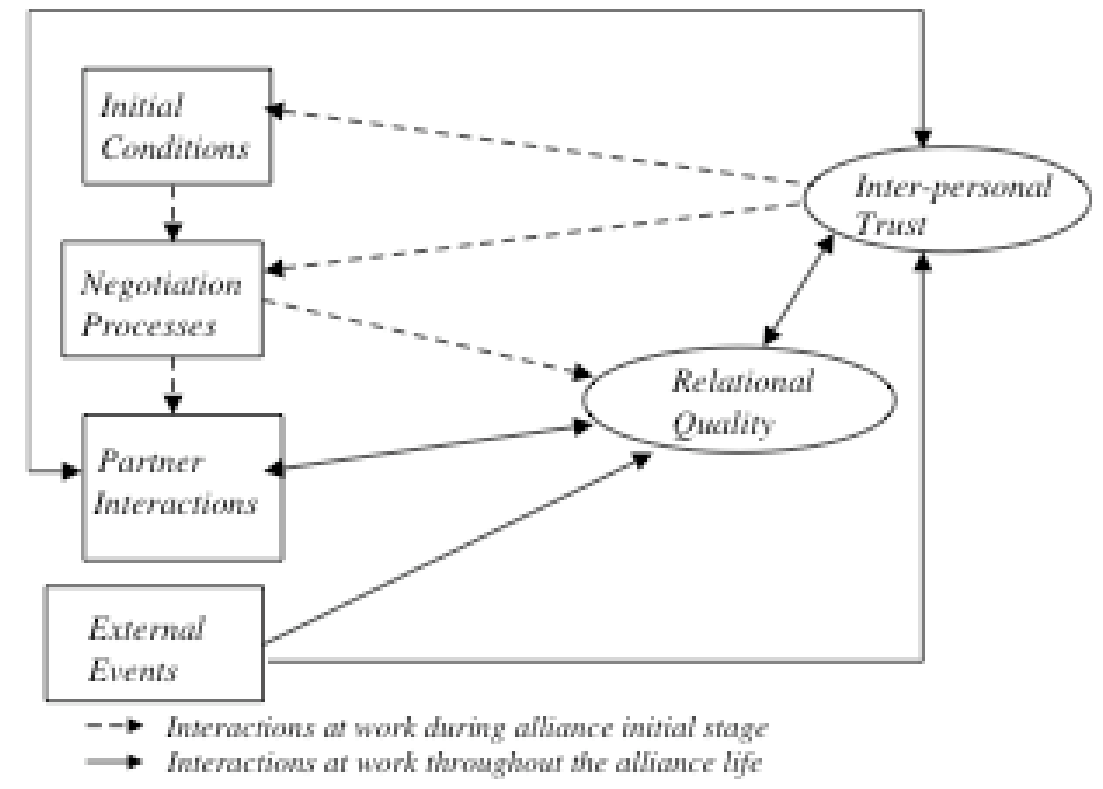

Figure 2: Dynamic interactions between relational quality and inter-personal trust (from Arino, de la Torre and Ring, 2005)

\section{Trust, Control attitude and Partnership effectiveness}

The success of a project implementing new technology is affected by relational quality through the attitudes displayed by the partner's principals and agents as they tackle issues confronting the project. Positive relational quality "permit partners to deal with risks with fewer problems" as (Arino et al. 2005, p. 17). On the other hand, negative relational quality is likely to trigger, for the partner who perceives it, a desire to increase control over the partner's contribution.

As the project develops, and as it is confronted with a change in the environmental conditions, the partners will continuously revise their views of each other and will also adjust their attitude in terms of control and trust.

Arino et al. (2005) posit that relational quality is affected by initial conditions (reputation, prior experiences), by the negotiation process that take place at the beginning of the project, by partners interactions (behavior, communication, advanced warning, etc.) and finally by external events such as those that affect the mother companies, key individuals, or even those of a systemic nature (economic or financial crises).

Inkpen and Curral (2004) also propose a dynamic approach of joint ventures in terms of trust and control in which they define two stages: initial and evolved conditions. In the 
first stage, the controls adopted by the joint venture partners are determined by the collaboration objectives and targets as well as trust between the two partners. As the joint venture operates under the controls set initially, partners will acquire new information about each other's capabilities, bargaining power, and behavior and will revise their level of trust that eventually will affect the joint venture stability. "High trust will decrease the likelihood that shifts in bargaining power will result in joint venture instability; low trust will increase the likelihood that shifts in bargaining power will result in joint venture instability" (Inkpen \& Currall, 2004, p. 595).

In their model, Inkpen \& Currall assume implicitly that control is set initially and not subject to revision. Without denying the importance of the first steps in a jointinnovation project (initial conditions and negotiations), as pointed out earlier, we know that great challenges also await partners as the joint project is on going. When confronting a major crisis, that requires a redefinition of the project goals and resources, we think that control is as likely as trust to be impacted. This is especially the case for partners' control on each other. For instance, following the late delivery of an important element in the project, we might observe that the partner's management might request tighter information against the jointly agreed schedule.

We therefore need a framework that allows the monitoring of joint development over time in terms of economic conditions, trust and organizational control.

\section{A Framework for the Relational Quality}

Certainly, a project's performance is determined by a large number of factors including technological, economic, social, financial considerations. Most of these factors, however, such as the financial market situation that affects the fund raising capacity of partners, are beyond their control.

The framework that we propose aims to monitor relational quality with a view to secure project performance. It is designed to offer a management tool for partners engaged in the implementation of a new technology (new at least for one of the partners) and in which both partners face a significant risk that they wish to minimize by close monitoring. For this reason, our methodology includes a set of indicators that need to be "informed" through a survey conducted regular intervals, so as to provide monitoring data.

The aim of this monitoring is to identify as early as possible a drift in the relational quality that increases the risk of lower performance of the project. It is therefore a tool 
for the managers and executives responsible for a project. Should a decline in relational quality be noticed, it is the joint responsibility of these project leaders to activate a set of initiatives in order to remedy the situation (Figure 3). Ideally, this monitoring should be done continuously but the time required to collect the data is not negligible and could be perceived as disturbing the regular activities of the project organization. It sounds reasonable to conduct the survey every two or three months, depending on the project duration, but it is necessary to keep track of events taking place during the partnership and to be recorded in a data log on a continuous basis (Figure 4). 
Figure 3: The Process for Monitoring Relational Quality

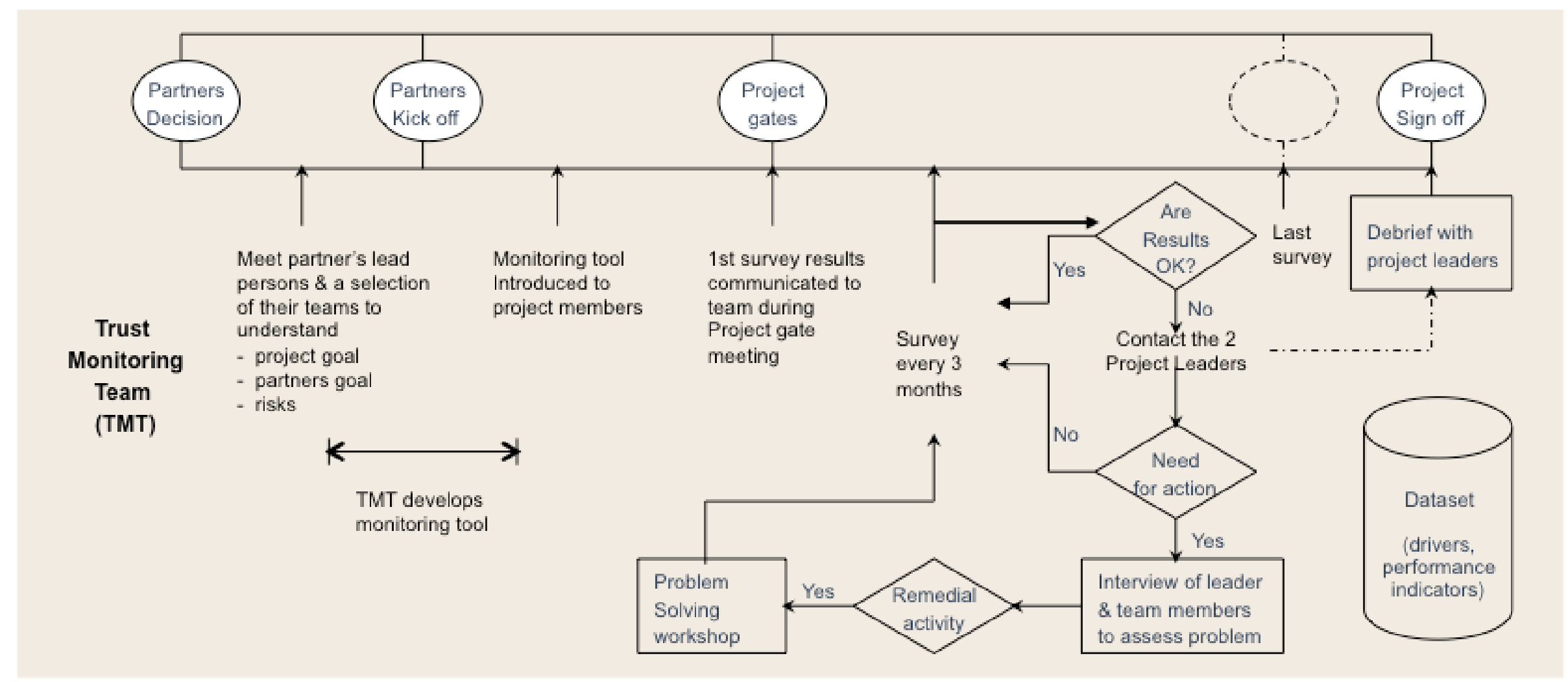


Figure 4: Data collected during the monitoring

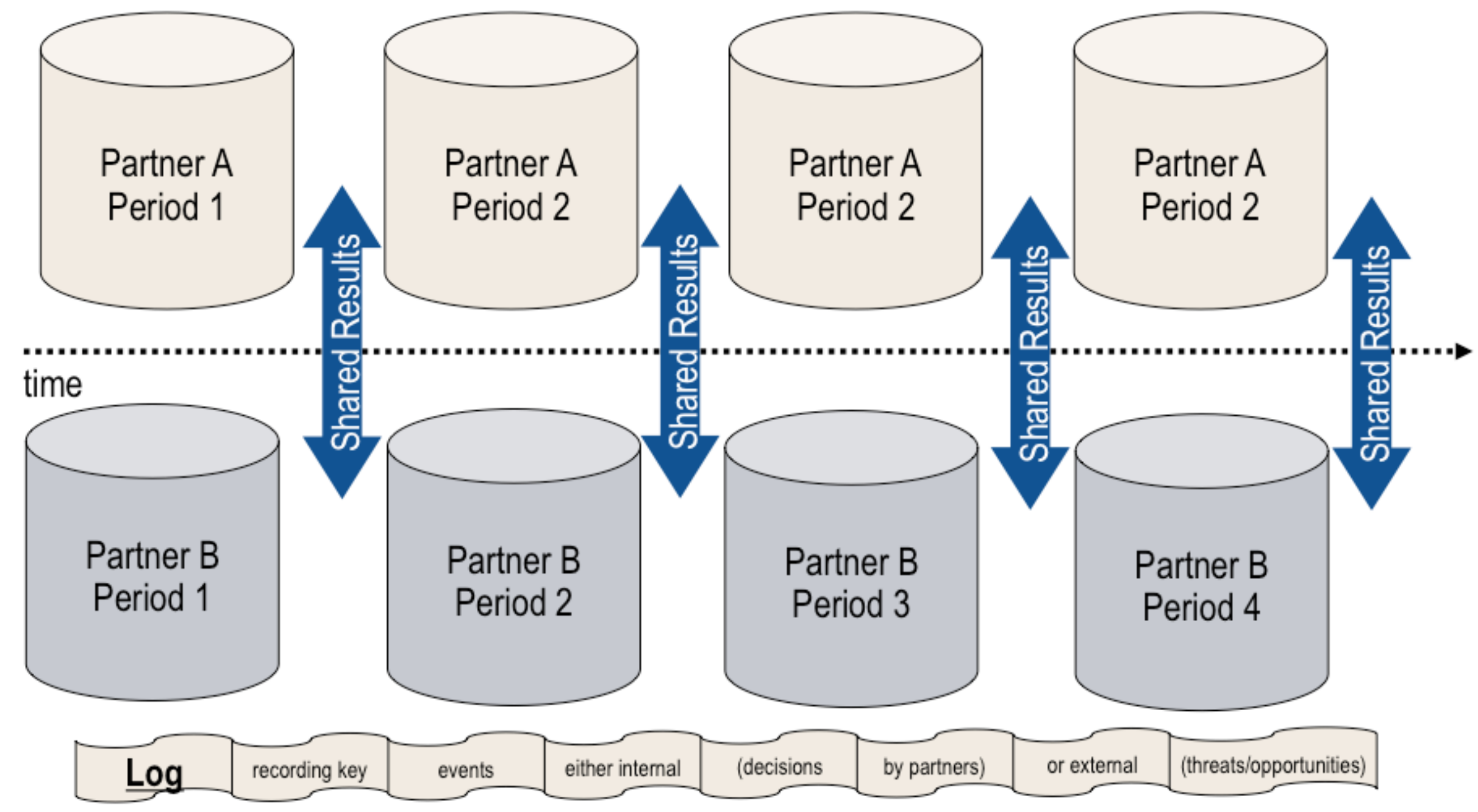




\section{Project performance and organization}

To the extent that relational quality is affected by a large number of individuals, the survey cannot be limited to project team members, although those are obviously critical to the atmosphere of the joint project.

A set of actors play a role in the evolution of relational quality (see Figure 5):

- The project “client”, i.e. the leader of the partner organizations' group (business unit, division, subsidiary) that will exploit the new technology.

- The team members, i.e. the individuals who are actually working on the deployment of the new technology. These may or may not be later on associated with its exploitation within the project "client". They belong to both the client and supplier organizations.

- The project leader, i.e. the person in charge of leading the joint team, generally from the supplier's side.

- The project sponsors, i.e. the person to whom the project leaders report. They are executives who have typically designed the agreement and possibly even signed the contracts associated with it.

- The corporate level, i.e. the "boss" of the sponsors, either directly or indirectly.

Figure 5: Levels of data

collection

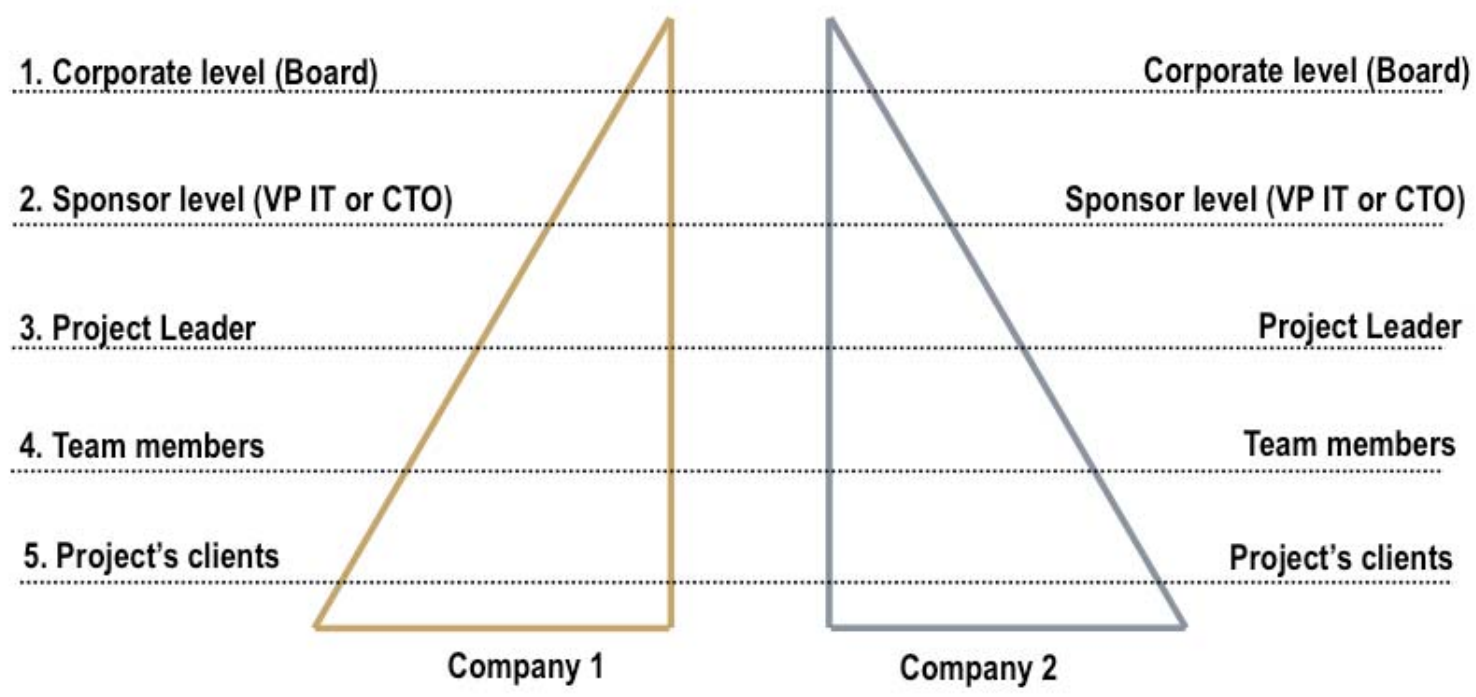

The nature of information collected at each level is different. This is because some data and insights are simply not known from all individuals involved in a partnership. For 
instance, cost targets are known by the project leaders and the sponsors but not necessarily by other team members. On the other hand, project's sponsors may not be aware of the behavior of the partner's staff, but team members who work with them daily are likely know this. Hence, our framework includes a set of survey tools customized to the different levels involved.

\section{A Model of Relational Quality and Project Performance}

In this section, we present the structure of our framework (Figure 6) for the monitoring of relational quality. This monitoring need to be conducted separately for each partner since it is clear that there can be a difference of perception between the two (or more) firms involved.

"Economic conditions" mean the set of factors affecting the risk of opportunism by the partners. These conditions are likely to change over the course of the project as the competitive context evolves. It is thus necessary to monitor, for instance, the switching costs of partners with each other.

"Personal trust" covers the perceptions of individuals responsible for the project success, i.e. the project sponsor, the project leader and the team members of both partners.

"Inter-organizational control" can be defined as the extent to which partners try to control each other partner in terms of planning, budgeting, and other administrative tools.

Both personal trust and inter-organizational control affect relational quality that we define, following Arino et al. (2005) as how comfortable partners deal with each others on the basis of trust.

We contend that relational quality will thus determine the attitude of the partners in terms of both trust and control.

"Trusting attitude" is measured by the perceptions of interviewees regarding some practices that are typical of trusting individual, e.g. knowledge sharing, transparency, equity, etc.

"Control attitude" is measured the perception of the interviewees regarding the other partner's behavior that suggest suspicion, e.g. double checking, second guessing, etc.

Finally, the performance of the project is measured, from both partners' perspective but also together. 
Figure 6: A Framework for the Monitoring of Relational Quality

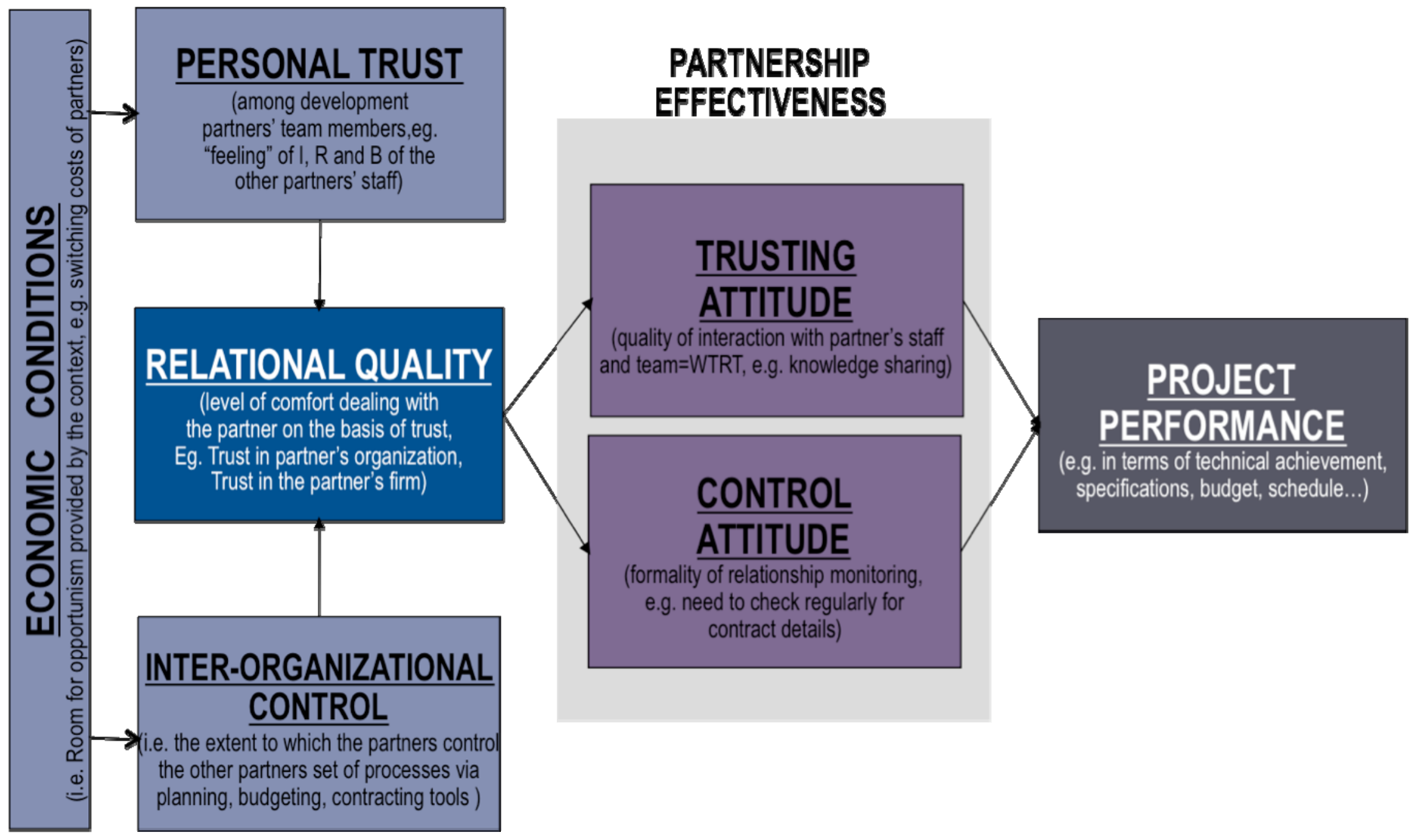




\section{Conclusion}

The present paper presents a methodology for the monitoring of relational quality applicable to joint development where partners come together to implement a new technology.

Our framework draws extensively on academic research on partnerships and proposes that the quality of relationship between partners is influenced by partners' behavior and attitude that oscillate between trust and control.

Relational quality being associated with partnership success, it would be useful to spot as early as possible drifts in the relationship that could later results in major disruptions, or even in project discontinuation. This framework is therefore useful for managers and executives responsible for projects involving collaboration with another organization.

The data collected can help anticipate tensions, but it can also permit a better understanding of the complex balance between trust and control. 


\section{Bibliography}

\section{REFERENCES}

Ariño A., De la Torre J., \& Ring P.S. 2004. Relational Quality: Managing Trust in Corporate Alliances. California Management Review, 44 (1): 109-131.

Ariño A., De la Torre J., \& Ring P.S. 2005. Relational quality and inter-personal trust in strategic alliances. European Management Review, 2 (1): 15-27.

Barczak G., Griffin A., \& Kahn K.B. 2009. Perspective: Trends and Drivers of Success in NPD Practices: Results of the 2003 PDMA Best Practices Study. Journal of Product Innovation Management, 26 (1): 3-23.

Berth R. 1993. The Return of Innovation. Kienbaum-Werkstudie, Duesseldorf: Kienbaum

Bidault F., Cummings T. 1994. Innovating through Alliances: Expectations and Limitations. R\&D Management, 24 (1): 33-45.

Bleeke J., Ernst D. 1993. Collaborating to Compete: Using Strategic Alliances and Acquisitions in the Global Marketplace, New York: John Wiley \& Sons

Christensen C. 1997. The Innovators Dilemma, Boston: Harvard Business School Press

Cooper R.G., Kleinschmidt E.J. 1987. New Products: What Separates Winners from Losers. Journal of Product Innovation Management, 4 (3): 169-184.

Cooper R.G. 2008. Perspective: The Stage-Gate Idea-to-Launch Process-Update, What's New, and NexGen Systems. Journal of Product Innovation Management, 25 (3): 213-232.

Das T.K., Teng B. 1998. Between Trust and Control: Developing Confidence in Partner Cooperation in Alliances. Academy of Management Review, 23 (3): 491-512.

Dyer J., Chu W. 2003. The role of trustworthiness in reducing transaction costs and improving performance: empirical evidence from the United States, Japan, and Korea. Organization Science, 14 (1): 57-68.

Ernst H. 2002. Success factors of New Product Development: A Review of the Empirical Literature. International Journal of Management Reviews, 4 (1): 1-40.

Gerybadze A. 2004. Technologie- und Innovationsmanagement: Strategie, Organisation und Implementierung, Muenchen: Vahlen

Hamm S. 2009. The Race for Perfect: Inside the Quest to Design the Ultimate Portable Computer, New York: McGraw-Hill

Henard D.H., Szymanski D.M. 2001. Why some New Products are more successful than others. Journal of Marketing Research, 38 (3): 362-375.

Inkpen A. C., Currall S. C. 2004. The coevolution of trust, control and learning in joint ventures. Organization Science, 15 (5): 586-599.

Kahn K.B. 2005. The PDMA Handbook of New Product Development, 2nd ed, Hoboken, N.J.: John Wiley \& Sons

Maital S. 1994. Executive Economics: Ten Essential Tools for Managers, New York: Free Press 
Montoya-Weiss M. M., Calantone R. 1994. Determinants of New Product performance: A Review and Meta-Analysis. Journal of Product Innovation Management, 11 (5): 397-417.

Ouchi W. 1979. A Conceptual Framework for the Design of Organizational Control Mechanisms. Management Science, 25 (9): 833-848.

Rosenbloom R., Christensen C. 1995. Technological Discontinuities, Organizational Capabilities, and Strategic Commitments. Industrial \& Corporate Change, 3 (3): 655-685.

Rothwell R. 1972. Factors for success in industrial innovations: Project SAPPHO - A Comparative Study of Success and Failure in Industrial Innovation, Science Policy Research Unit, University of Sussex, Brighton, UK.

Rousseau D.M., Sitkin S.B., \& Burt R.S., \& Camerer C. 1998. Not so different after all: A crossdiscipline view of trust. Academy of Management Review, 23 (3): 393- 404.

Sagard A. 2006. Technological Innovation. The Encyclopedia of Earth, September 5, 2006 (http://www.eoearth.org/article/Technological_innovation, accessed on November 25th, 2009)

Schumpeter J.A. 1912. Theorie der wirtschaftlichen Entwicklung (transl. 1934, The Theory of Economic Development), Leipzig: Duncker \& Humblot

Utterback J.M. 1994. Mastering the Dynamics of Innovation: How Companies Can Seize Opportunities in the Face of Technological Change, Boston: Harvard Business School Press

Zaheer, A., McEvily B., \& Perrone V. 1998. Does trust matter? Exploring the effects of interorganizational and interpersonal trust on performance. Organization Science, 9 (2): 141159. 


\section{Recent ESMT Working Papers}

\begin{tabular}{|c|c|c|}
\hline & $\begin{array}{l}\text { ESMT } \\
\text { No. }\end{array}$ & $\begin{array}{l}\text { Competence } \\
\text { Center }\end{array}$ \\
\hline $\begin{array}{l}\text { A Framework for Monitoring Relational Quality in B2B Technology } \\
\text { Partnerships }\end{array}$ & $09-008$ & $\begin{array}{l}\text { Management } \\
\text { and }\end{array}$ \\
\hline $\begin{array}{l}\text { Francis Bidault, ESMT } \\
\text { Manfred Lüth, University of Nice } \\
\text { Olaf Plötner, ESMT }\end{array}$ & & Technology \\
\hline $\begin{array}{l}\text { Enjoy! Assertive Language and Consumer Compliance in (Non)Hedonic } \\
\text { Contexts }\end{array}$ & 09-007 & $\begin{array}{l}\text { Management } \\
\text { and }\end{array}$ \\
\hline $\begin{array}{l}\text { Ann Kronrod, Tel-Aviv University } \\
\text { Amir Grinstein, Ben-Gurion University of the Negev } \\
\text { Luc Wathieu, ESMT }\end{array}$ & & Technology \\
\hline $\begin{array}{l}\text { ISO 9000: New Form of Protectionism or Common Language in } \\
\text { International Trade? }\end{array}$ & $09-006$ & $\begin{array}{c}\text { European } \\
\text { Competitiveness }\end{array}$ \\
\hline \multicolumn{3}{|l|}{$\begin{array}{l}\text { Joseph A. Clougherty, University of Illinois at Urbana-Champaign } \\
\text { Michat Grajek, ESMT }\end{array}$} \\
\hline $\begin{array}{l}\text { Demography vs. Context: A Cross-Country Survey of the Willingness to Rely } \\
\text { on Trust in Business Partnerships }\end{array}$ & 09-005 & $\begin{array}{l}\text { Management } \\
\text { and }\end{array}$ \\
\hline $\begin{array}{l}\text { Francis Bidault, ESMT } \\
\text { José R. de la Torre, Florida International University } \\
\text { Stelios H. Zanakis, Florida International University }\end{array}$ & & Technology \\
\hline $\begin{array}{l}\text { Regulation and Investment in Network Industries: Evidence from European } \\
\text { Telecoms }\end{array}$ & $09-004$ & $\begin{array}{l}\text { European } \\
\text { Competitiveness }\end{array}$ \\
\hline \multicolumn{3}{|l|}{$\begin{array}{l}\text { Michat Grajek, ESMT } \\
\text { Lars-Hendrik Röller, ESMT }\end{array}$} \\
\hline $\begin{array}{l}\text { Access Regulation and Investment in Next Generation Networks: A Ranking } \\
\text { of Regulatory Regimes }\end{array}$ & $09-003$ & $\begin{array}{l}\text { European } \\
\text { Competitiveness }\end{array}$ \\
\hline \multicolumn{3}{|l|}{$\begin{array}{l}\text { Rainer Nitsche, ESMT } \\
\text { Lars Wiethaus, ESMT }\end{array}$} \\
\hline $\begin{array}{l}\text { The Effect of Adversity on Process Innovations and Managerial Incentives } \\
\text { Benoit Dostie, HEC Montréal } \\
\text { Rajshri Jayaraman, ESMT }\end{array}$ & 09-002 & $\begin{array}{l}\text { Management } \\
\text { and } \\
\text { Technology }\end{array}$ \\
\hline $\begin{array}{l}\text { An Empirical Approach to Understanding Privacy Concerns } \\
\text { Luc Wathieu, ESMT } \\
\text { Allan Friedman, John F. Kennedy School, Harvard University }\end{array}$ & $09-001$ & $\begin{array}{l}\text { Management } \\
\text { and } \\
\text { Technology }\end{array}$ \\
\hline $\begin{array}{l}\text { Cosmopolitanism, Assignment Duration, and Expatriate Adjustment: The } \\
\text { Trade-Off between Well-Being and Performance }\end{array}$ & 08-011 & Leadership \\
\hline \multicolumn{3}{|l|}{$\begin{array}{l}\text { Luc Wathieu, ESMT } \\
\text { Amir Grinstein, Guilford Glazer School of Business and Management, Ben } \\
\text { Gurion University of the Negev }\end{array}$} \\
\hline $\begin{array}{l}\text { Trust and Creativity: Identifying the Role of Trust in Creativity-oriented } \\
\text { J oint-developments }\end{array}$ & 08-010 & $\begin{array}{l}\text { Management } \\
\text { and }\end{array}$ \\
\hline $\begin{array}{l}\text { Francis Bidault, ESMT } \\
\text { Alessio Castello, Georgia Tech France }\end{array}$ & & Technology \\
\hline
\end{tabular}




\section{ESMT}

European School of Management and Technology GmbH

Schlossplatz 1

10178 Berlin

Germany

Phone: +49 (0)30212 31-1279

www.esmt.org 